\title{
A Comparative Analysis of Berith and the Sacrament of Baptism and How They Contributed to the Inquisition
}

\author{
Yehonatan Elazar-DeMota
}

Citation: Elazar-DeMota, Yehonatan 2021. A Comparative Analysis of Berith and the Sacrament of Baptism and How They Contributed to the Inquisition. Religions 12: 346. https://doi.org/10.3390/rel12050346

Academic Editor: Henri Gooren

Received: 22 March 2021

Accepted: 8 May 2021

Published: 13 May 2021

Publisher's Note: MDPI stays neutral with regard to jurisdictional claims in published maps and institutional affiliations.

Copyright: (C) 2021 by the author. Licensee MDPI, Basel, Switzerland. This article is an open access article distributed under the terms and conditions of the Creative Commons Attribution (CC BY) license (https:// creativecommons.org/licenses/by/ $4.0 /)$.
T.M.C. Asser Instituut, 2500 GL Den Haag, The Netherlands; yelazar613@gmail.com

\begin{abstract}
In 1391 Spanish Jews were forcibly converted to Catholic Christianity, and Portuguese Jews suffered the same fate in 1497. Jewish law rendered involuntary converts as anusim and voluntary converts as meshumadim. Christians without Jewish ancestry called them by various names, New Christians, alboraique, xuetas, and marranos, to name a few. In the fifteenth century, Catholic clerical authorities debated whether the New Christians were indeed Christians, albeit coerced. Canonic law rendered the sacrament of baptism as irrevocable. As such, any belief or practice not in accordance with Catholic doctrine was tantamount to heresy. Consequently, the Inquisition sought to rid the Church of the "Judaizing heresy." On the one hand, the Sinaitic covenant (berith) considered anusim as Jews, even though there were Christians. This paper analyzes Jewish law and canonic law on respective religious identities. It includes an examination of rabbinic texts and rabbinic responsa, and an examination of the sacrament of Christian baptism. Both religious traditions fought for the souls of the anusim, characterizing what Victor Turner calls liminality and communitas.
\end{abstract}

Keywords: Sephardic Jews; anusim; conversos New Christians; baptism; sacrament; halakhah; berith; Inquisition

\section{Introduction}

Until about two centuries ago, people of Iberian descent were persecuted under the suspicion of being called "Judaizers" by the Holy Office throughout a timespan of nearly four hundred years. Many of them thinking to escape terror became subject to piracy at sea, losing all of their financial possessions, and even to the doom of death. Whether these people were living in the "New World", the African continent, Western Europe, or India, their lives were at peril as long as they had a trace of "New Christian" lineage. Though a number of them were indeed sincere converts to Christianity, some of their descendants chose to keep the flame of their ancestral traditions ablaze. "During the day, they went about as exemplary Catholics, attended Mass, went to confession, and had their children baptized. But on certain nights they met secretly in one another's homes, reverted to Hebrew names, and read from the Torah" (Elazar-DeMota 2015, p. 1; Kritzler 2014, p. 4). It is these latter ones that received the derogatory label of "Marranos". The double lifestyle of the conversos, compelled the Spanish, Portuguese, and Italian clerical authorities to extirpate all heresy from the Church. The analyses of the Inquisition tribunals suggest that the Church was at war with those parishioners having any trace of "Jewish blood." The inquisitors targeted the Judaizing "New Christians" due to the divergence between the following two religious concepts: the inviolable Catholic sacrament of baptism, and on the other hand, the Hebraic concept of berith.

Cultural anthropologist Victor Turner (1920-1983) introduced the concepts of liminal personae and communitas. In the Ritual Process (1969), he defines liminal entities "betwixt and between the positions assigned and arrayed by law, custom, convention, and ceremonial" (Turner 1969, p. 95). Turner uses the Latin term communitas to describe the subcultures within a structured society. Essentially, they are a phenomenon of transition (Turner 1969, pp. 111-12). 
This paper discusses how Catholic canonic law and Jewish law, as interpreted by early modern religious authorities, contributed to the liminal identity of Iberian conversos. This exploration will require an analysis of identity from both Jewish and Christian texts. Accordingly, the Jewish sources consulted and examined are the Hebrew Bible, the Talmud, Moses Maimonides' Mishneh Torah, and the responsa literature of the sixteenth-century Ottoman Sephardic religious authorities. In the same fashion, the paper examines the Apostolic writings and Catholic canonic law. The first section explores Israelite identity within the Hebrew Bible and its development thereof by medieval and Jewish religious authorities during the Inquisition time period (1481-1834). The second section explores the legal parameters of Christian identity by way of the Apostolic writings and Catholic legal texts. The third and fourth sections examine the Jewish identity of the Iberian conversos. The last section presents a comparative analysis between Christian and Jewish identity, within the context of the Inquisition. In juxtaposing the two, the author highlights the liminal status of the Iberian conversos.

\subsection{The Hebrew Covenant}

One of the most peculiar Jewish phenomenological ideas to grasp is the Jewish identity. Being "Jewish" transcends nationality, race, and religious belief. Since it transcends nationality, one can be born in any country of the world and be a Jew. Moreover, since people from different ethnicities can convert into the Jewish people, race is meaningless. Most important, a Jew that is raised as a Christian, Muslim, Buddhist, or any other creed, can return to the faith of the Jewish people. Jews have lived in various regions of the world for over 2500 years, and yet have experienced unity through their covenantal bond. The Hebrew word for covenant is berith (ברית), which denotes an agreement between two contracting parties, and sealing it with blood. Thus, God entered into a berith with Abraham, by which He entered into a special bond with him and his descendants forevermore (Jewish Publication Society 1985, Gen. 15:18). The sign by which this covenant is sealed is through the rite of circumcision (Jewish Publication Society 1985, Gen. 17:2-7). According to the Jewish tradition, this covenant was renewed with the Children of Israel and the mixed multitude at Sinai. The people exclaimed, "Everything that the ETERNAL ONE has commanded, we will do, then understand" (Jewish Publication Society 1985, Exo. 19:8). This mystical union of Israel and God is exemplified in the guarding of the weekly Sabbath. Also, this covenant transcends human time. According to the Hebrew Bible, Moses ratifies the Sinaitic covenant with all generations of the Israelites at his last speech before his death (Jewish Publication Society 1985, Deut. 29:15). Ultimately, the words of the covenant were etched in stone and kept in the "Ark of the Covenant" as a reminder of this event. Hence, the Hebrew scriptures convey the idea that this berith includes all generations of Israelites, irrespective of where one may have been born, and those that join the people of Israel from other nations.

\subsection{The Post Exilic Jewish Identity}

The Jewish identity further develops after the Babylonian exile during the time of the Persian rule over the Near East. Ezra, Nehemiah, and their cohorts were faced with a new challenge that posed a threat to the national identity of the Jews. The Torah already stated, "Don't intermarry with them. Don't give your daughter to one of their sons to marry, and don't take one of their daughters to marry your son, because they will turn your child away from following me so that they end up serving other gods" (Jewish Publication Society 1985, Deut. 7:3-4). The Men of the Great Assembly took it upon themselves to extend this prohibition from the seven Canaanite nations to exclude women from Ashdod, Ammon, and Moab (Jewish Publication Society 1985, Neh. 13:23). Whereas the Torah declares a person as part of the Hebrew people through patrilineal descent, the Jewish Sages declared one to be a Jew through matrilineal descent. This is evidenced in the Talmud where R'Shimeon b. Yohai derives from the Torah text (Deb. 7:3-4) that "your son" refers to the one born from an Israelite mother, whereas "your son by a heathen mother 
is not considered to be yours" (Artscroll 1997, b. Qidd.68b). One authority by the name of Jacob, from the village of Gubiriya suggested that the Israelite identity should follow the patrilineal descent (Artscroll 2010, y.Qidd. 3:12). However, the consensus vehemently ruled in opposition to his opinion, in agreement to the principle that the court follows the majority. At this point, it is necessary to define various statuses of Israelites in the Talmud, namely, Meshumad, Apikorus, Min, Tinoq Shenishbah leben hagoyim, and Anus.

\subsubsection{Meshumad}

Maimonides codified in his Yad Hehazaqah, the Talmudic law in regards to the statuses of Jews, depending on their behavior and/or belief. He states, "And these are those that do not have a portion to the world to come: the heretics, the Epicureans, those who deny the Torah, those who deny the resurrection, those who deny the coming of a redeemer ..." (Maimonides et al. 2010c, M.T. Hil. Teshubah 3:14) The meshumad or apostate is defined as the follows:

Someone who has made a practice of willfully committing a particular sin [to the point where] he is accustomed to committing it and his deeds are public knowledge ... in regard to him, it is as if this precept has been nullified entirely. Such a person is considered an apostate in regard to that matter. This applies [only] if he [commits the sin] with the intent of angering God. An example of an apostate in regard to the entire Torah is one who turn to the faith of the gentiles when they enact [harsh] decrees [against the Jews] and clings to them, saying: "What value do I have in clinging to Israel while they are debased and pursued. It's better to cling to those who have the upper hand." Such an individual is an apostate in regard to the entire Torah. (Maimonides et al. 2010c, M.T. Hil. Teshubah 3:18)

The latter case was applied to those Jews on Spanish soil that converted voluntarily in order to climb the social ladder or to escape death. This issue is discussed extensively in the responsa literature of the early modern Sephardic authorities in exile.

\subsubsection{Apikorus}

The Talmudic authorities dealt with Hellenized Jews during their day. These were called the Apikorosim or Epicureans. According to Talmudic law, there are three types of Israelites that fall under this category, they are as follows: "one who denies the existence of prophecy and maintains that there is no knowledge communicated from God to the hearts of men; one who disputes the prophecy of Moses, our teacher; and one who maintains that the Creator is not aware of the deeds of men" (Maimonides et al. 2010c, M.T. Hil. Teshubah 3:16). In contemporary times, rabbinic authorities consider atheistic Jews as Apikorosim. During the forced conversions of Spain in 1391, undoubtedly there were some Jews who could be classified as such. They neither desired to be observant Jews, nor hypocritical Christians. However, conversion was the more favorable choice, lest they perish. Thus states Yitzchak Baer, "so many Jews sought baptism that the supply of holy anointing oil in the church soon gave out" (Baer 1993, p. 101).

\subsubsection{Min}

Maimonides lays out the conditions for a min, or heretic, in his Mishneh Torah. He states that the following five are considered minim (plural of $\mathrm{min}$ ):

One who says there is no God nor ruler of the world; one who accepts the concept of a ruler, but maintains that there are two or more; one who accepts that there is one Master [of the world], but maintains that He has a body or form; one who maintains that He was not the sole First Being and Creator of all existence; one who serves a star, constellation, or other entity so that it will serve as an intermediary between him and the ETERNAL LORD. (Maimonides et al. 2010c, M.T. Hil. Teshubah 3:15) 
According to this legal decision, it is evident that a Jew would be considered a heretic for adhering to Christian doctrine, namely, the sanctity of the Holy Trinity, the divinity of Jesus, the co-eternity of God the Son, the Immaculate Conception and incarnation of God in the person of Jesus, and the intermediary and intercessory work of Jesus in Heaven. For that matter, some Jews could not accept converting to Catholicism and preferred to die as martyrs. Baer explains that, "In Madrid most of the Jews were killed or baptized ... some of the Jews of Burgos were baptized, and a whole quarter inhabited by conversos soon sprang up" (Baer 1993, p. 99). The latter of the two will be the topic of this analysis.

\subsubsection{Tinoq Shenishbah Leben Hagoyim}

The Talmudic Rabbis dealt with cases of children that were sequestered by nonIsraelites. This implies that an Israelite was held captive as a child and redeemed as an adult. The legal ramifications raise many questions. Is this Israelite responsible for upholding the precepts? Is such a person held culpable for violating the prohibitions on the Sabbath? $\mathrm{Rab}$ and Shemuel rule that a sequestered Israelite by any of the nations, and a proselyte, are not held culpable for the errors that they commit until they become knowledgeable about their acts (Artscroll 2010, b. Šabb.68b). Maimonides adds the following:

The children of these errant people and their grandchildren whose parents led them away and who were born among this heresy and raised according to their conception, they are considered as a child captured and raised by them. Such a child may not be eager to follow the path of precepts, for it is as if he was compelled not to. Even if later, he hears that he is Jewish and saw Jews and their faith, he is still considered as one who was anus (compelled against observance), for he was raised according to their mistaken path. This applies to those who we mentioned who follow the erroneous path of their ancestors. Therefore, it is appropriate to motivate them to repent and draw them to the power of the Torah with words of peace. (Maimonides et al. 2010b, M.T. Hil. Mamerim 3:3)

Maimonides was speaking about the children of those born into heretical sects of Jews that denied the oral tradition (Karaites). This ruling can be applied appropriately to the descendants of both voluntarily and involuntarily Jewish converts to Catholicism. The latter ones are known as the anusim and bene anusim in the rabbinic responsa.

\subsubsection{Anus}

The most important legal term used in the Talmud that applies to the conversos and their descendants is anus, i.e., coerced or compelled. The Talmud defines an Israelite that is found in a position where he or she cannot fulfill a precept as anus. One can have two precepts to fulfill at one moment, but only have the possibility to fulfill one of the two, and this person is anus. Those Iberian Jews that were forcibly converted to Catholicism are considered anusim, since the socio-political construct did not allow for them to practice the Jewish tradition openly. Also, the lack of knowledge of the legal ramifications of a specific precept also classifies an Israelite as anus (Maimonides et al. 2010a, M.T Hil. Šeb. 3:7). Moreover, the Rabbis exempt all anusim from taking offerings to the Temple for their errors, on the grounds that they were not able to fulfill the precepts (Maimonides et al. 2010a, M.T Hil. Šeg. 10:10). Finally, the Rabbis exempt all anusim from corporal punishments (Artscroll 2010, b.B.Qam.31a; b.Ned. 27a). The anusim and their descendants will be discussed in more detail later in this paper.

The liminal status of the conversos, possessing simultaneous identities as Jews and Christians, was the result of the meeting of Jewish law and Catholic canonic law. According to Jewish law, a coerced Jew cannot lose his status and neither the descendants of coerced Jewesses. On the other hand, according to Catholic canonic law, a sacrament such as baptism cannot be revoked, thereby sealing the identity of the individual as Christian for all eternity. This duality contributed to the converso communitas during the Inquisition time period. The next section will examine the institution of the sacrament of baptism. 


\section{Catholic Sacraments}

Otto Gisler defines a sacrament as "a visible sign instituted by Jesus Christ, through which invisible grace and sanctification are communicated with us" (Gisler 1888, p. 37). Baptism is the first of seven sacraments of the Roman Apostolic Catholic Church. The others include confirmation, holy Eucharist, penance, extreme unction, holy orders, and matrimony. The sacraments were instituted by the Church, under the assistance of the Holy Spirit in order to increase reverence and respect. Since they are considered to be led by the Holy Spirit, essentially, they cannot be nullified. Many cases throughout the history of the Catholic Church have raised the issue of exceptions to this rule. It will be shown briefly how the sacrament of baptism created dissension among the Church authorities during the forced conversions of 1391 in Spain and 1497 in Portugal.

\subsection{Baptism in the Apostolic Writings}

The Apostolic writings speak of two types of baptisms, namely, the "baptism of John," and the "baptism of Jesus." The former was a physical immersion that demonstrated sincere repentance and the messianic expectation. The latter refers to the physical immersion in the "name of Jesus," for the forgiveness of sins, and the reception of the Holy Spirit.

\subsection{The Baptism of John}

The Gospel of Matthew states, "At that time Jesus came from Galilee to the Jordan River so that John would baptize him" (American Bible Society 1995, Mat. 3:13). Robert Webb argues that John was part of the Essene Jewish sect (Webb 2006, p. 351). He is not alone on this theory. This theory is based on the notion that John's baptism is related to the daily ablution of the Essenes. It is interesting that Jesus comes to be baptized by John, thereby demonstrating the need for repentance of his sins. According to the Book of Acts, those Jews who cherished immediate messianic expectations were baptized by John or by his followers as a sign of repentance (American Bible Society 1995, Acts 13:24). After the resurrection of Jesus, a modified form of baptism was implanted by his followers.

\subsection{Baptism in the Name of Jesus}

In Gospel, according to Matthew, Jesus commands his disciples, “Therefore, go and make disciples of all nations, baptizing them in the name of the Father and of the Son and of the Holy Spirit" (American Bible Society 1995, Mat. 28:19). The Apostle Paul contrasts John's baptism with Jesus', stating, "John baptized with a baptism by which people showed they were changing their hearts and lives. It was a baptism that told people about the one who was coming after him. This is the one in whom they were to believe. This one is Jesus" (American Bible Society 1995, Acts 19:4). It can be inferred from these passages that John prepared the way for Jesus' messianic movement to spread throughout Judea and the Jewish diaspora. Moreover, Jesus told his apostles, "John baptized with water, but in only a few days you will be baptized with the Holy Spirit" (American Bible Society 1995, Acts 1:5). During the Pentecost, many Jews from various nations were gathered at the Temple in honor of the precept to present their offerings 50 days after the Paschal lamb offering. At that moment, after the apostles began speaking in intelligible languages, in astonishment of the diaspora Jews, Peter proclaimed, "Change your hearts and lives. Each of you must be baptized in the name of Jesus Christ for the forgiveness of your sins. Then you will receive the gift of the Holy Spirit" (American Bible Society 1995, Acts 2:38). Overall, the Apostolic writings portray baptism in Jesus' name, as evidenced by the power of the Holy Spirit.

\subsection{Baptism in Catholic Canonic Law}

\subsubsection{Conversion}

The catechism of the Catholic Church states, "Baptism constitutes the foundation of communion among all Christians, including those who are yet in full communion with the Catholic Church ... " (Libreria Editrice Vaticana 1997, 1271). Moreover, paragraph number 1272 states the following: 
Incorporated into Christ by baptism, the person baptized is configured to Christ. Baptism seals the Christian with the indelible spiritual mark (character) of his belonging to Christ. No sin can erase this mark, even if sin prevents Baptism from bearing fruits of salvation. Given once for all, Baptism cannot be repeated. (Libreria Editrice Vaticana 1997, 1272)

Baptism as performed by the Catholic Church involves the "immersion of the body or the pouring of water upon the head of the candidate, while pronouncing the invocation of the Most Holy Trinity: the Father, the Son, and the Holy Spirit" (Libreria Editrice Vaticana 1997, 1278). According to these canonic principles, the sacrament of baptism cannot be revoked nor repeated. When the Iberian Jews were forced to convert between 1391 and 1497, some Church authorities argued that their conversion was not acceptable since it was forced upon them. For example, Isidore of Seville considered conversion under the fear of death to be forced conversion, thereby invalid (Netanyahu 1995, p. 1014). Nevertheless, the majority consensus cited the canonic principles to uphold their inclusion into Christ. As a result, so many "New Christians" were considered heretical by the Catholic Church officials, since they did not abandon the practice Jewish rituals. The outcome was the inevitable Inquisition.

\subsubsection{Christening}

Another important form of inclusion into the Church is that of infant baptism. This ceremony is known as the Christening. Catholic doctrine teaches that children have the need of baptism, being that they are born with a "fallen human nature tainted by original sin." Hence, catechism of the Catholic Church states the following:

The practice of infant baptism is an immemorial tradition of the Church. There is explicit testimony to this practice from the second century on, and it is quite possible that, from the beginning of the apostolic preaching, when whole "households" received baptism, infants may have also be baptized. (Libreria Editrice Vaticana 1997, 1252)

"New Christians" throughout the Inquisition time period continued to take their children to be christened by the priests. However, upon arriving home, their parents would wash their children's heads, as to undue the effects of the holy water. To their dismay, the inquisitors considered them to be part of the "Body of Christ," prohibiting them to disassociate themselves from the Church.

\section{The Jewish Identity of the Anusim}

To the Church, the forced Jewish converts were coreligionists, albeit insincere in many cases. Whereas the Church authorities responded with the Inquisition, the Sephardic rabbinic authorities wrote numerous responsas in regards to the inalienable connection to the Jewish people of the anusim through their birthright. The responsas will demonstrate how the Sephardic sages during the first two centuries of the Inquisition dealt with the identity and reintegration of the anusim into the Jewish communities throughout North Africa and the Ottoman Empire.

\subsection{Fifteenth-Century Rabbinic Responsa on Coerced Jews in Spain (1391-1492)}

The most important rabbinic literature on the anusim was written in the fifteenth century by the authorities that fled from Spain to North Africa in the late fourteenth and fifteenth centuries, Yiṣhaq b. Shesheth Barfet, Shime'on b. Șemah Durán, Solomon b. Shimeon Durán, and Abraham ibn Zimra. They based their rulings on the following Talmudic principles:

\subsubsection{Modus Operandi}

In the Babylonian Talmud (Artscroll 2010, b.Hul.12a) we learn that wherever the facts can be ascertained, we must do so, and wherever one cannot, we follow the majority. Thus, the shohet (ritual slaughterer) is considered valid since the majority of people with the same modus operandi are known to be professionals in the ritual slaughtering and their laws. 
Therefore, those peoples claiming to be Jews from Spain demonstrate that they follow the same modus operandi of the majority of the Jews.

\subsubsection{A Portion Extracted from a Heterogeneous Majority}

In the Babylonian Talmud (Artscroll 2010, b.Hul.95a) we learn to follow the majority because anything separated from a heterogeneous group is regarded as having been separated from the majority. The case we are dealing with here is about ten butcher shops found in a city, where nine of them are of Israelites and one is non-Israelite. If a nonIsraelite sells meat to an Israelite, the law is that the Israelite can eat it, since we presume that the meat came from the majority. Therefore, someone leaving the Iberian Peninsula and presenting himself/herself before a Beth Din (rabbinic tribunal) can be established as being Jewish, based upon the notion that the majority of those peoples leaving Iberia during the Inquisition are indeed Jews, since they originate from the majority of the group of anusim, whose mothers were Jewish.

\subsubsection{Profit loss}

In the Talmud (Artscroll 2010, b.B.Mes.5b) we learn that where there is no profit for the person involved, we assume that he/she does not transgress through lying. This principle is applied to those anusim that left their possessions, comfort, and lifestyles in order to return to the Jewish practice openly in another land. We presume that he or she does not lie about being Jewish because of all of the losses at stake.

\subsubsection{A Dying Person and Oaths}

In the Talmud (Artscroll 2010, b.Šeb.42b) we learn from a case about a collection of payments to the Temple, that a person is not required to make an oath, since we presume that no one conspires to defraud the Temple. However, this applies to the dying person because there is no profit gain on his or her behalf. During the Inquisition time (1482-1834), it is understood that the Holy Office persecuted the New Christians and their descendants. Therefore, this principle would apply to those anusim leaving Iberia to practice the Jewish tradition openly.

Overall, the aforementioned authorities established a legal presumption that the anusim were born of Jewish mothers, and that there is no suspicion about their lineage, since they generally did not marry "Old Christians". They also agreed that the coerced ones were obligated to leave the Catholic lands. Interestingly, many post-fifteenth-century authorities started to condemn those that continued to reside in Spain.

\section{Sixteenth-Century Rabbinic Responsa on the Coerced Jews in Portugal in 1497 \\ 4.1. Qiddushin and Gittin of the Anusim}

One of the most challenging cases for the Sephardic authorities to deal with was in regards to the status of the Jewish marriages of those Portuguese conversas that left their husbands behind. According to Torah law, a woman cannot remarry without having received a bill of divorcement from her husband (Gittin in plural) (Jewish Publication Society, Deut. 24:1-4). If a woman in such a case happened to remarry or have a child out of wedlock, she would be considered an adulteress and her child would be considered a mamzer (bastard and illegitimate child who cannot marry into the Congregation of Israel). During the time of the forced conversions and Inquisition, some couples were separated due to a difference in opinion. Sometimes, some of these women wanted to leave their husbands to be able to practice the Jewish tradition openly in another land, against the whims of their husbands. The legal ramifications are clear as to her future relationships and descendants. Rabbi Shemuel de Medina, representing the Sephardic tribunal at Thessaloniki ruled in the following manner in such a cases:

...In a previous (early) agreement, it was written and signed in Salonika, may God be its defense, about the anusim in Portugal and wherever they are, to inform to all those who see this writing of ours, that it was agreed upon by all the 
Sages of this city, the city of Salonika etc... That all woman who are married to any man from the Sons of Israel while they are under the coercive/destructive decree, even when they have qiddushin (Jewish marriage) witnessed by other Israelites standing there, who watched the water of destruction over their heads [baptism], that one must not be concerned about (the validity) of those qiddushin whatsoever, so that she is allowed to marry any man who wants to marry her, either in the place of the decree, or after being rescued from the sword of the decree. And thus we act in this city (Salonika), that any woman coming from Portugal, we are not concerned about her marital consecration after the decree, and we allow her to marry with any man she wills, for the reason that there are no valid testimonies whatsoever there and, since the witnesses are not valid, there are no qiddushin whatsoever. If she remain also in need of Levirate marriage, she has no connection at all and doesn't need a haliṣáh document at all, and they are allowed to get married etc.

(signatures) Ya'aqob ben Habib, Shelomoh Taytazaq, Me'ir 'Arama', Yosef Piso (Fiso), Mosheh 'Arukím, 'Eli'ézer haShime’oní. (Medina 1589; Lampronti 1840, p. 75)

This ruling was based on the notion that the witnesses were invalid, since they could not keep the precepts correctly. Hence, even though a marriage was performed with Jewish witnesses, their testimony is invalid, thereby invalidating the marriage. Thus, according to this tribunal, those unions were considered as a man with a concubine.

\subsection{Legal Presumption of Anusim}

The Safed-based sage, Yom Tob b. Moshe Șahalón ruled, "There is no suspicion that a person that comes to return to Judaism is of a non-Jewish mother, since the anusim have legal presumption that they marry among themselves, especially the Portuguese" (S.ahalón 1694, pp. 107, 148). Once again, the lineage of the Portuguese anusim are not put into doubt a priori, since they did not marry with non-Jews. This was the case since the Portuguese Jews were converted en masse in 1497, and were generally sincere adherents to the Jewish tradition in secret. Ultimately, the Sephardic authorities generally agreed that the Iberian anusim were Jews, albeit living an outward Christian lifestyle, while being endangered.

\section{Berith vs. Sacrament}

After having analyzed both the Hebrew concept of berith and the Catholic sacrament of baptism, it is evident that Iberian Jews were placed in a difficult situation. According to Jewish law, they were Jewish and according to Catholic canonic law, they were Christians, subject to the scrutiny of the Holy Office of the Inquisition. The forced conversions of 1391,1492 , and 1497, respectively, created identity crises for many Jewish families. Within one family, some members desired to be genuine Christians, whereas others wanted to be faithful to the tradition of their ancestors. José Faur (1934-2020) asserts that there were the following four types of Spanish conversos: those who desired to be faithful Christians and to have minimal contacts with other Jews; those who wanted to live as Jews; those who wanted to maintain simultaneous Jewish and Christian identities; and those who wanted neither (Elazar-DeMota 2015, p. 83; Faur 1992, p. 117). Those that wanted to sever ties with other Jews were overwhelmed with anti-Jewish sentiments (Elazar-DeMota 2015, p. 83; Faur 1992, p. 118). Those that kept practicing the Jewish tradition, albeit in secret. On the Sabbath, they held secret Jewish services, while praying at the local church on Sunday. Others viewed Christianity as a means to escape violence. Some conversos lived as good Christians, while retaining some Jewish elements. In fact, some of the inquisitors were of Jewish stock, such as the infamous Torquemada. Moreover, the Chief Rabbis of Burgos (Solomon Halevi) and Castile (Abraham Senior) became sincere Christians and even attempted to convince other Jews to follow suit. Another class of conversos were irreligious as Jews and skeptical about Christianity. 
While the Holy Office of the Inquisition sought to strengthen the Catholic Empire by weeding out the Church from Judaizing heretics, rabbinic authorities in North Africa, the Ottoman Empire, and Western Europe, wrote treatises against the Catholic faith, hoping to convince the anusim to return to the open practice of the Jewish tradition outside of las tierras de idolatría (Spain and Portugal). For example, Profiat Durán wrote Kelimath haGoyim. In addition, Hasday Crescas wrote Bittul Iqqaré Dath Iqqaré haNoșrim. Apologetic rabbinic literature continued to appear throughout the eighteenth century, with the sole purpose of redeeming the long lost Jewish "souls" to Catholicism. This warring of souls continued until the abolishment of the Portuguese Inquisition in 1821 and the Spanish Inquisition in 1834.

\section{Conclusions}

Stemming from split identities, the converso's internal mental war, contributed to the crypto-Jewish phenomenon. Joshua Loth Liebman maintains, "For if each man is created in the image of God, and God is one-then it follows that if man allows himself to become a split soul, and inwardly warring personality, he actually denies his Divine image" (Liebman 1946, p. 19). Building on Liebman's premise, one could argue that the early modern converso experience did not only affect their position within the Iberian society, but also their psychologies and spiritual destinies.

Possessing simultaneous Jewish and Christian identities, converos formed part of their own communitas, i.e., a subculture within the structured Catholic society. They were neither here nor there, but betwixt and between. At the core of this anti-structure lied the theological concepts berith and sacramento. Although both of these metaphysical ideas had different origins and were separated by space and time, they converged during the Inquisition time period, contributing to converso liminality and communitas. Both the sacrament of baptism and the Sinaitic berith were deemed as irrevocable by the respective Christian and rabbinic clergy. Ultimately, Iberian anusim represent Turner's phenomenon of transition.

Funding: This research received no external funding.

Institutional Review Board Statement: Not applicable.

Informed Consent Statement: Not applicable.

Data Availability Statement: Not applicable.

Acknowledgments: I would like to thank Steven Vose, Tudor Parfitt, and Ana María Bidegain from Florida International University.

Conflicts of Interest: The author declares no conflict of interest.

\section{References}

American Bible Society. 1995. Holy Bible: Contemporary English Version. Philadelphia: American Bible Society.

Artscroll. 1997. The Babylonian Talmud. Schottenstein. New York: Artscroll Mesorah Publications.

Artscroll. 2010. The Jerusalem Talmud. Schottenstein. New York: Artscroll Mesorah Publications.

Baer, Yitzhak. 1993. A History of the Jews in Christian Spain. Philadelphia: Jewish Publication Society.

Elazar-DeMota, Yehonatan. 2015. Spanish and Portuguese conversas: A model for Sephardic Jewry under the Ashkenazic hegemony. Journal of Student Research 1: 25-35.

Faur, José. 1992. In the Shadow of History: Jews and Conversos at the Dawn of Modernity. New York: State University of New York Press. Gisler, Otto. 1888. Catholic Worship: The Sacraments, Festivals, and Worship of the Church. Cincinnati: Benziger Brothers.

Jewish Publication Society. 1985. The Jewish Bible: Tanakh: The Holy Scriptures-The New JPS Translation According to the Traditional Hebrew Text: Torah, Nevi'im, Kethuvim. Philadelphia: The Jewish Publication Society.

Kritzler, Edward. 2014. Jewish Pirates of the Caribbean: How a Generation of Swashbuckling Jews Carved Out an Empire in the New World in Their Quest for Treasure, Religious Freedom-And Revenge. London: Aurum Press.

Lampronti, Isaac. 1840. Páhadh Yisháq, Vol 6. Mekise Nirdamim.

Libreria Editrice Vaticana. 1997. Catechism of the Catholic Church: Revised in Accordance with the Official Latin Text Promulgated by Pope John Paul II. Rome: Libreria Editrice Vaticana.

Liebman, Josh Loth. 1946. Peace of Mind. New York: Simon and Schuster Inc. 
Maimonides, Moses, Yehi'el M. Zilber, and Me'ir A. Horoṿits. 2010a. Mishneh Torah: Hilkhot Šegagoth. Jerusalem: Mekhon Moreshet haNesher Hagadol.

Maimonides, Moses, Yehiel M. Zilber, and Me'ir A. Horovits. 2010b. Mishneh Torah: Hilkhot Mamerim. Jerusalem: Mekhon Moreshet haNesher Hagadol.

Maimonides, Moses, Yehiel M. Zilber, and Me'ir A. Horovits. 2010c. Mishneh Torah: Hilkhot Teshubah. Jerusalem: Mekhon Moreshet haNesher Hagadol.

Medina. 1589. Responsa = 2 כרכים. (ד"צ למברג תרכ"ב). שמואל בן משה די מדינה:שאלות ותשובות. ניו-יורק, תשי".

Netanyahu, Benzion. 1995. The Origins of the Inquisition in Fifteenth Century Spain. New York: Random House Publishing.

Sahalón, Yom Tob b. Moshe. 1694. Responsa Maharis HeHadashoth, Venice, Italy.

Turner, Victor. 1969. The Ritual Process: Structure and Anti-Structure. New Brunswick: Aldine Transaction.

Webb, Robert. 2006. John the Baptizer and Prophet: A Social-Historic Study. Eugene: Wipf and Stock Publishers. 